\title{
THE REGULATION OF STRUCTURAL PARAMETERS OF CERAMICS DEPENDING ON THE DRYING REGIME
}

\author{
Romualdas Mačiulaitis ${ }^{1}$, Jurgita Malaiškienè ${ }^{2}$ \\ Dept of Building Materials, Vilnius Gediminas Technical University, Saulètekio al. 11, \\ LT-10223 Vilnius, Lithuania \\ E-mail: ${ }^{1}$ romualdas.maciulaitis@st.vgtu.lt, ${ }^{2}$ jurgita.malaiskiene@st.vgtu.lt \\ Received 20 Jan 2009; accepted 11 May 2009
}

\begin{abstract}
Always in the shaped semimanufactures of ceramics is some humidity, which we must eliminate before burning. Drying process is to safeguard the satisfactory strength of semimanufactures. Additionally, changes of ceramic samples capacity is to end the drying process, associated with elimination of humidity that would not compose defects - gaps, fractures, fragmentation etc. In this work it was shown, how the selected stages of drying regime influence the structural parameters of ceramics (reserve of porous volume, heterogeneity degree of structure, maximum rate of capillary rise according to watering front, capillary rate of mass flow, water absorption) and vice verse, how the selection of the dimensions of the stages for drying regime depends on the desired values of the of ceramics.
\end{abstract}

Keywords: ceramics, structural parameters, drying regime, statistical analysis.

\section{Introduction}

The companies purpose is to control better technological processes, maximum computerized and optimized manufacture. We want quickly and expressly appreciate the influence of every factor on final product. The scientists for this purpose have created various programs and calculating methods (Alinaitwe et al. 2007; Ginevičius et al. 2008; Zavadskas et al. 2008). In the factory of building ceramics one of the main processes is drying.

Drying the semimanufactures of ceramics, defects are discovered in them, because free water between the particles of clay is drifting away; the particles of clay move closer to each other, and the dimensions of the product decrease. During the shrinkage mechanical strains are produced, which may exceed the allowable limits because of too fast water drift; consequently a semi-manufacture cracks, even though the burning process has not started yet (Ткачев и др. 1999). While drying volumetric variations can be divided into 3 phases. In the first phase, the shrinkage is directly proportional to the amount of humidity evaporated, in which particles are close but do not come into contact. There is no proportion of the shrinkage to the amount of evaporated humidity in the second phase. The shrinkage increasingly falls behind a decrease in water amount. The particles of clay come into contact and pores emptied are filled with air. In the third phase clay does not shrink, because the humidity is decreasing, porosity of the semimanufacture gradually increases. The first and partly the second phases are the most dangerous, because semimanufactures shrink, and therefore they must be dried slowly at that point (Šiau- čiūnas 2001). But it remains unclear, what in any case the tentative time of drying must be.

The authors (Lewis 2000; Briscoe et al. 1998) have offered to divide drying process into two parts: linear drying of ceramics (when moisture is removed from capillaries) and non-linear, when moisture is removed from pores in the method of vapour-diffusion. These authors have determined that drying of ceramics especially depends on the level of humidity of a sample and drying temperature.

Some authors (Amoros et al. 2003; Barati et al. 2003) have shown how the properties of semimanufactures of ceramics depend on the moisture of substance and drying time. They have determined that the drier material is, and at the same time drying will be held for a longer time (three and more days at the maximum temperature of about $100^{\circ} \mathrm{C}$ ), the greater mechanical strength is obtained. For example, as water moisture equals $5 \%$, strength $-0.5 \mathrm{MPa}$, when water absorption equals $1 \%$, the strength of analysed ceramics $-1.6 \mathrm{MPa}$.

In some scientific works (Mihoubi et al. 2002; Nascimento et al. 2006) it has been shown, how drying temperature of the ceramic semimanufactures influences the quality of the final product. This product was dried at the temperature of $30{ }^{\circ} \mathrm{C}, 50{ }^{\circ} \mathrm{C}, 60{ }^{\circ} \mathrm{C}, 70^{\circ} \mathrm{C}, 80^{\circ} \mathrm{C}$. It was determined that the most qualitative ceramic articles which reach the greatest strength (approximately from $2 \mathrm{MPa}$ to $6 \mathrm{MPa}$ ) are obtained when drying semimanufactures at 70$80^{\circ} \mathrm{C}$. In other works (Croft, Sheffield 1994; Kosykh et al. 2003 ) it has been analysed the maximum influence of drying temperature on the quality of ceramic chip. It was shown how defects of the product vary in the maximum temperature interval of $10-150{ }^{\circ} \mathrm{C}$. It was determined that 
it is the best way to dry ceramic semimanufactures at 20 $110{ }^{\circ} \mathrm{C}$. According to authors (Croft et al. 1994), firstly we need to dry ceramic semimanufactures not less than a day at $20^{\circ} \mathrm{C}$, then at $60^{\circ} \mathrm{C}$ for 6 hours, and at the maximum drying temperature of $110^{\circ} \mathrm{C}$ for 24 hours. An article dries gradually and macroscopic splits do not adjust. According to authors (Kosykh et al. 2003), ceramic semimanufactures need to be dried at $85^{\circ} \mathrm{C}$ for $11 \mathrm{~h}$ and later at $100{ }^{\circ} \mathrm{C}$ for obtaining a fixed mass.

In our previous works (Mačiulaitis et al. 2008; Mačiulaitis et al. 2007) it was mostly emphasised the interdependence between physical-mechanical indexes and parameters of drying regime. However, we failed in finding scientific works, where the influence of drying temperature and other drying factors on structural indexes of ceramics are analysed. Moreover, there is no one mind what the duration of drying and the temperature of ceramic semimanufactures must be. In order to solve the mentioned problems, we need to analyse and validate how each phase of drying regime influences particular properties of ceramic samples. Moreover, we need to determine the best drying regime according to parameters and it has been accomplished in this work.

\section{Characteristics of materials, research methods}

In our investigations, easily fusible clay from Girininkai deposit (chemical composition in Table 1) was determined by classical methods of chemical analysis of silicate substances, was used as the main product.

Granulometric composition of this deposit, which shows how many and how large there are particles in the clay, is presented in Table 2.

Table 1. The chemical composition of used clay

\begin{tabular}{c|c|c|c|c|c|c|c|c}
\hline \multicolumn{1}{c}{ Chemical composition, \% } \\
\hline $\mathrm{SiO}_{2}$ & $\mathrm{Al}_{2} \mathrm{O}_{3}+\mathrm{TiO}_{2}$ & $\mathrm{Fe}_{2} \mathrm{O}_{3}$ & $\mathrm{CaO}$ & $\mathrm{MgO}$ & $\mathrm{K}_{2} \mathrm{O}$ & $\mathrm{Na}_{2} \mathrm{O}$ & $\mathrm{SO}_{3}$ & L.O.I. \\
\hline 47.66 & 18.32 & 6.27 & 8.11 & 3.04 & 2.68 & 0.16 & - & 12.60 \\
\hline
\end{tabular}

Table 2. The granulometric composition of clay

Size of fraction (mm) and amount (\%)

\begin{tabular}{c|c|c|c|c|c|c}
\hline $0.5-0.2$ & $0.2-0.09$ & $0.09-0.06$ & $0.06-0.01$ & $0.01-0.005$ & $0.005-0.001$ & Less than 0.001 \\
\hline 0.20 & 0.10 & 0.08 & 4.58 & 9.28 & 24.28 & 61.48 \\
\hline
\end{tabular}

Table 3. Drying regimes

\begin{tabular}{c|c|c|c|c|c|c|c}
\hline $\begin{array}{c}\text { Drying } \\
\text { regime }\end{array}$ & $\begin{array}{c}\text { Drying } \\
\text { degree of } \\
\text { samples } \\
\%\end{array}$ & $\begin{array}{c}\text { Stage of drying } \\
\text { in a laboratory } \\
y_{l},\end{array}$ & $\begin{array}{c}\text { Temperature } \\
\text { of drying in a } \\
\text { laboratory } \\
{ }^{\circ} \mathrm{C}\end{array}$ & $\begin{array}{c}\text { Duration of } \\
\text { drying in a } \\
\text { laboratory } \\
\mathrm{h}\end{array}$ & $\begin{array}{c}\text { Stage of dry- } \\
\text { ing in the } \\
\text { electric stove } \\
y_{2},\end{array}$ & $\begin{array}{c}\text { Temperature of } \\
\text { drying in the } \\
\text { electric stove } \\
{ }^{\circ} \mathrm{C}\end{array}$ & $\begin{array}{c}\text { Duration of } \\
\text { drying in the } \\
\text { electric stove } \\
\mathrm{h}\end{array}$ \\
\hline 1 & 5.10 & 5.44 & 20 & 48 & 0 & 20 & 0 \\
\hline 2 & 23.0 & 8.16 & 20 & 168 & 35.37 & 65 & 48 \\
\hline 3 & 21.9 & 20.95 & 22 & 504 & 17.69 & 65 & 72 \\
\hline 4 & 22.3 & 41.9 & 22 & 336 & 28.57 & 105 & 48 \\
\hline 5 & 22.4 & 8.16 & 20 & 72 & 11.73 & 105 & 6 \\
\hline 6 & 23.9 & 17.14 & 18 & 168 & 7.14 & 105 & 12 \\
\hline 7 & 28.5 & 57.14 & 20 & 72 & 42.86 & 105 & 96 \\
\hline 8 & 25.7 & 17.14 & 18 & 168 & 40.82 & 150 & 48 \\
\hline
\end{tabular}






Fig. 1. The evaluation of the relative square measurements of drying regime

In order to evaluate the heat in the samples according to Fig. 1 (Table 3, the fourth drying regime: the stage of drying in the laboratory - at $22^{\circ} \mathrm{C}$ for $336 \mathrm{~h}$ and the stage of drying in the electrical stove - at $105^{\circ} \mathrm{C}$ for $48 \mathrm{~h}$ ), first of all we double the values of temperature and the time of keeping at it:

$$
\begin{aligned}
& y_{1}{ }^{\prime}=22 \cdot 336=7392, \\
& y_{2}{ }^{\prime}=48 \cdot 105=5040 .
\end{aligned}
$$

In this way all the drying regimes are evaluated and the biggest sum of the conditional areas is equated to 100 . Then proportion is applied (in this case the biggest area was 17 640). So:

$$
\begin{gathered}
y_{1}=(7392 \cdot 100) / 17640=41.9 \\
y_{2}=(5040 \cdot 100) / 17640=28.57
\end{gathered}
$$

Dried samples were burned in the electrical stove selecting the same burning regime to all the batches. It was burned for $36 \mathrm{~h}$ keeping at the maximum temperature of $1050{ }^{\circ} \mathrm{C}$ for three hours (Fig. 2).



Fig. 2. Graph of burning regime

Selected (5 from 10 samples of representing batches) encaustic blocks were used to determine the structural indexes according to 1 (LST EN 771-1+A1 2005; Mačiulaitis 1996; Мачюлайтис 1997; Mačiulaitis, Malaiškienė 2008; Malaiškienė, Mačiulaitis 2004).
Grouping the results of the investigation which were obtained and preparation for the regression analysis were performed with „Microsoft Excel“" and „Statistica“ programs. Statistical analysis of the structural indexes obtained was performed according to literature (Čekanavičius, Murauskas 2002; Sakalauskas 1998; Манита 2001). Regularity of constraint was investigated applying such functions: linear $(y=a+b x)$, quadratic $(y$ $\left.=a+b x^{2}\right)$, degree $\left(y=a x^{b}\right)$, exponential $\left(y=a b^{x}\right)$, degree-exponential $\left(y=a x^{\mathrm{b}} \cdot \mathrm{c}^{x}\right)$, hyperbolical $\quad(y=$ $1 /(a+b x))$, fractional rational $\left(y=x /\left(a+b x+c x^{2}\right)\right)$, modified exponential $\left(y=a e^{b x}\right)$, model of Tornkvist $(y=$ $a x /(b+x))$, polynomial $\left(y=a+b x_{1}+c x_{2}+\ldots+d x_{1} x_{2}+\ldots+\right.$ $\left.+b x_{1}{ }^{2}+c x_{2}^{2}+\ldots\right)$ and mathematical model with epoch $((y=a+b x)(y<$ const.$)+(y=a+b x)(y>$ const.$))$ (Čekanavičius, Murauskas 2002; Sakalauskas 1998). In order to determine the mathematical relation, it was selected the function describing the most precisely the character of data distribution, also which multidimensional correlation and determination coefficients are the closest to one. Multidimensional correlation coefficient is described as square root of determination coefficient $R^{2}$; it has negative value in case of negative regression and positive when the regression is positive (Ostle et al. 1996).

Determination coefficient $R^{2}$ shows the suitability of the model (Čekanavičius, Murauskas 2002; Kleinbaum et al. 1998).

It was checked if distribution of the experimental results is normal, using Kolmogorov-Smirnov criterion (Graybill, Iyer 1994). If the value of this criterion is lower than it is indicated in the statistical table (it is selected according to the number of the samples and the level of magnitude (in our case 0.05)), the distribution of data is considered normal. For example, when we analyse 40 values of the samples, at magnitude level of 0.05 , the value indicated in Kolmogorov-Smirnov statistical table is 0.210 (Graybill, Iyer 1994).

Adequacy of the obtained equations was checked according to Ficher criterion. If the mentioned index of the equation is bigger than the one indicated in the standard table, the equation is considered adequate and suitable for data description. For example, as we investigate 40 samples, at magnitude level of 0.05 , the value indicated in the table of Ficher criterion equals 2.44 (Sakalauskas 1998). The magnitude of the variables of the equation was determined according to Stjudent criterion. If the value of the index is bigger than in the standard table (as we investigate 40 samples, at magnitude level of 0.05 , the value indicated in the table of Stjudent criterion equals 2.02), so the index is considered significant (Čekanavičius, Murauskas 2002).

Average values of investigated structural indices determined are presented in Table 4 and Fig. 3.

Table 4 and Fig. 3 show that analysed values of structural indexes were fluctuating significantly. Moreover, it was obtained a ceramic chip belonging to the second group according to effective porosity $\left(\mathrm{W}_{\mathrm{e}}>26 \%\right)$ (Mačiulaitis 1996; Мачюлайтис 1997). 
Table 4. Average values of structural indices of ceramic samples

\begin{tabular}{c|c|c|c|c|c}
\hline Batch & $\begin{array}{c}R_{p} \\
x_{1}, \\
\%\end{array}$ & $\begin{array}{c}N_{h} \\
x_{2}\end{array}$ & $\begin{array}{c}H_{\max } \\
x_{3}, \\
\mathrm{~mm}\end{array}$ & $\begin{array}{c}g \\
x_{4}, \\
\mathrm{~g} / \mathrm{cm}^{2}\end{array}$ & $\begin{array}{c}W_{h} \\
x_{5} \\
\%\end{array}$ \\
\hline 1 & 19.16 & 1.017 & 49.3 & 1.045 & 21.62 \\
\hline 2 & 23.34 & 0.392 & 27.3 & 0.473 & 17.93 \\
\hline 3 & 24.63 & 0.390 & 27.3 & 0.396 & 17.61 \\
\hline 4 & 24.35 & 0.918 & 26.3 & 0.436 & 17.74 \\
\hline 5 & 16.66 & 0.470 & 25.3 & 0.487 & 19.22 \\
\hline 6 & 21.79 & 0.493 & 29.0 & 0.520 & 17.55 \\
\hline 7 & 26.86 & 0.262 & 17.7 & 0.255 & 16.63 \\
\hline 8 & 22.07 & 0.826 & 21.0 & 0.334 & 19.41 \\
\hline
\end{tabular}

here: $R_{p}$ - rezerve of porous volume, $N_{h}$ - heterogeneity degree of structure, $H_{\max }$ - maximum rate of capillary rise according to watering front, $g$ - capillary rate of mass flow, $W_{h}-$ water absorption.

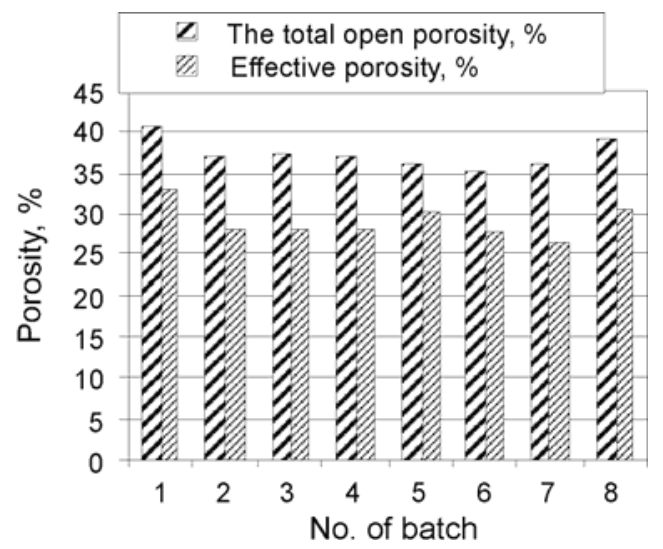

Fig. 3. Average values of common open and effective porosities

Mostly, when changing drying regime, and all the other technological specifications were fixed, heterogeneity degree of structure was fluctuating from approximately 0.2 ( the 7 th batch) to 1 (first batch), maximum rate of capillary rise according to watering front was fluctuating approximately from $17 \mathrm{~mm}$ (the 7 th batch) to $50 \mathrm{~mm}$ (the first batch) and capillary rate of mass flow which was fluctuating from $0.25 \mathrm{~g} / \mathrm{cm}^{2}$ (the 7 th batch) to $1 \mathrm{~g} / \mathrm{cm}^{2}$ (the 1 st batch).

The results which we obtained indicate that drying regime determines strongly final properties of the ceramic article; therefore it is important to know how each dimension of the drying regime stage influences structural indexes of the ceramic chip.

We determined the influence of the dimensions of the selected drying stage on the structural values by performing statistical analysis.

\section{Statistical analysis}

It is determined, that distribution of experimental values of investigated structural indexes is normal, therefore it is possible to form adequate empirical equations. The values of Kolmogorov-Smirnov criterion are obtained from 0.07 to 0.199 , and value given in statistical table in our investigated case is 0.210 (Graybill, Iyer 1994). Mathematical model with epoch was selected to describe experimental data, because it mostly corresponds to the character of data distribution and its correlation and determination coefficients were the closest to 1 . Other investigated models, such as linear, quadratic, logarithmic, degree, exponential etc., have got much lower values of determination coefficient. Similar values of determination coefficient (as in mathematical model with epoch) we obtained to polynomial of the 3rd and the 4th degree. However, those equations do not reveal physical meaning of investigated indexes which interests us.

Empirical equations, which results make sure of a higher reliability, show more precise tendencies of change of investigated indexes and allow us to use equations when producing ceramic articles were formed according to the experiments results. Therefore, in one case structural indexes of ceramics are $x$, and in the reverse case $-y$, in order not to cause misunderstanding, while deriving empirical equations, we do not change the notations of indexes. Also, investigating empirical equations we made the assumption that interpretation of obtained equations do not have to defy logic. For example, according to mathematical dependence, we would obtain that structural indexes determine drying temperature of semimanufacture, but structural indexes of temperature cannot influence. On the contrary, drying temperature determines values of the final qualitative characteristics of ceramics.

We will examine dependency of structural indexes on selected drying stages according to 5-9 empirical equations.

$$
\begin{gathered}
x_{1}=\left(17.95-0.047 y_{1}+0.097 y_{2}\right)\left(x_{1}<22.36\right)+ \\
\left(22.92+0.052 y_{1}+0.010 y_{2}\right)\left(x_{1} \geq 22.36\right),
\end{gathered}
$$

$x_{2}=\left(0.438-0.003 y_{1}-0.001 y_{2}\right)\left(x_{2}<0.656\right)+$

$\left(2.199-0.069 y_{1}-0.003 y_{2}\right)\left(x_{2} \geq 0.656\right)$,

$x_{3}=\left(31.23-0.224 y_{1}-0.108 y_{2}\right)\left(x_{3}<29.50\right)+$

$\left(49.74+0.731 y_{1}-1.245 y_{2}\right)\left(x_{3} \geq 29.50\right)$,

$x_{4}=\left(0.471-0.004 y_{1}-0.001 y_{2}\right)\left(x_{4}<0.535\right)+$

$\left(1.239-0.004 y_{1}-0.016 y_{2}\right)\left(x_{4} \geq 0.535\right)$,

$x_{5}=\left(17.76+0.019 y_{1}+0.001 y_{2}\right)\left(x_{5}<18.23\right)+$

$\left(20.74-0.040 y_{1}-0.018 y_{2}\right)\left(x_{5} \geq 18.23\right)$.

Multidimensional correlation and determination coefficients and average standard deviations of empirical equations 5-9 are presented in Table 5. 
Table 5. Multidimensional correlation $R$ and determination $R^{2}$ coefficients, average standard deviations $s_{e}$ of empirical Eqs 5-9

\begin{tabular}{c|l|c|c|c}
\hline Eqs & \multicolumn{1}{|c|}{ Indexes } & $R$ & $R^{2}$ & $s_{e}$ \\
\hline 5 & $\begin{array}{l}\text { Reserve of porous } \\
\text { volume, } x_{1}\end{array}$ & 0.881 & 0.777 & $1.33 \%$ \\
\hline 6 & $\begin{array}{l}\text { Degree of heterogene- } \\
\text { ity of structure, } x_{2}\end{array}$ & 0.926 & 0.858 & 0.16 \\
\hline 7 & $\begin{array}{l}\text { Maximum rate of cap- } \\
\text { illary rise according to } \\
\text { watering front, } x_{3}\end{array}$ & 0.895 & 0.801 & $5.11 \mathrm{~mm}$ \\
\hline 8 & $\begin{array}{l}\text { Capillary rate of mass } \\
\text { flow, } x_{4}\end{array}$ & 0.896 & 0.803 & $0.13 \mathrm{~g} / \mathrm{cm}^{2}$ \\
\hline 9 & Water absorption, $x_{5}$ & 0.845 & 0.714 & $0.85 \%$ \\
\hline
\end{tabular}

Multidimensional correlation coefficients of Eqs 59 are quite close to one, therefore we state that relation between investigated indexes is strong, and determination coefficients are higher than 0.7 (Table 5), therefore mathematical model is selected properly. Average standard deviations are low enough, therefore real (obtained in experiment) values calculated according to empirical equations will differ slightly.

Empirical Eq 5 shows how reserve of porous volume varies subject to values of drying regime stages. The stage of drying in a laboratory before and after epoch $(22.36 \%)$ influences differently values of index of reserve of porous volume. In order to obtain higher than $22.36 \%$ (empirical Eq 5) reserve of porous volume, we need to increase value of the drying stage in a laboratory. The stage of drying in a stove influences positively the reserve of porous volume, i.e. the higher reserve of porous volume we want to obtain, the higher this drying stage we need to select. This can happen because more slowly and gradually the free moisture evaporates from big open pores and capillaries, particles of substance are getting closer to each other making smaller and more closed pores and capillaries. Semi-manufacture is shrinking equally and splits do not appear. Volumetric and exploitative frost resistance depends mostly on the value of reserve of porous volume. Therefore, we can also increase volumetric and exploitative frost resistance of final products when keeping ceramic samples for appropriate time in a laboratory and in the electrical stove.

We can work out from the data of empirical equation 6 and Table 5, how selected values of the stages of drying regimes influence index of degree of the structure heterogeneity. This index is influenced negatively by the stage of drying in a laboratory and the stage of drying in the electrical stove before and after epoch $(0.656)$, as effective porosity of ceramic chip is higher than $26 \%$, i.e. the higher we want to get the index of degree of heterogeneity of structure, the lower we select values of stages of drying in a laboratory and in the electrical stove. This can be explained, that the more quickly semimanufactures are being dried (i. e. the lower stages of drying in a laboratory and in the electrical stove ), the more slowly free moisture evaporates from the samples, which later evaporates too quickly as semimanufacture assumes a higher amount of heat making a lot of pores and capillaries, which are ranged in disorder. Eq 7 shows the dependence of the index of maximum rate of capillary rise according to watering front on the selected drying parameters. The value of the stage of drying in a stove influences negatively this index. The higher stage of drying in the electrical stove, the lower maximum rate of capillary rise according to watering front we obtain. The stage of drying in a laboratory before and after epoch (29.5 mm (Eq 7)) influences differently the maximum rate of capillary rise according to watering front. The lower maximum rate of capillary rise according to watering front we want to obtain, the higher stage of drying in a laboratory we have to select. This can happen because drying the articles more slowly, the degree of defects of samples decreases, samples are obtained of equal structure, and burning semimanufactures more closed pores and capillaries are being formed. Therefore, if we select too intensive stage of drying in a laboratory, free moisture will not evaporate gradually in time and cracks will form, and the values of maximum rate of capillary rise according to watering front will start to increase.

From the data of Eqs 8 and 5 in the table, we can see how the rate of capillary flow depends on selected values of drying stages. The values of drying stages influence negatively values of mentioned structural index. The lower the capillary rate of mass flow we want to obtain, the higher values of drying stages we need to select. That is logical, because the better sample dries, i.e. free and part of absorbent moisture evaporate more evenly, the better they parch, the possibility of defects and diameter of open pores and capillary decrease when later burning semimanufactures. That is why the sample absorbs a lower amount of water.

Eq. 9 shows, how water absorption is influenced by the values of drying stages. The stage of drying in a laboratory influences negatively this index, i.e. the lower water absorption we want to obtain, the higher stage of drying in a laboratory we need to select. The stage of drying in the electrical stove influences differently before and after epoch (18.23\% (Eq 9)). The lower water absorption $(<18.23 \%)$ we want to obtain, the higher value of the stage of drying in the electrical stove we select. This can be explained that, a lower number of defects arises in the samples which have a higher degree of drying. Dependence of theoretical (calculated according to obtained empirical equations) and factual (determined in experimental way) values of water absorption is presented in Fig. 4.

We will prove hypothesis which was formed, when deriving Eqs 10-11 of reciprocal dependence

$$
\begin{aligned}
& y_{1}=\left(2.49+0.57 x_{1}-0.72 x_{2}+0.46 x_{3}-7.62 x_{4}-0.27 x_{5}\right) \\
& \left(y_{1}<24.11\right)+\left(340.2-3.23 x_{1}+37.3 x_{2}-4.42 x_{3}+\right. \\
& \left.260.7 x_{4}-12.5 x_{5}\right)\left(y_{1} \geq 24.11\right), \\
& y_{2}=\left(-20.0+0.82 x_{1}-1.33 x_{2}-0.32 x_{3}-4.21 x_{4}+1.50 x_{5}\right) \\
& \left(y_{2}<22.43\right)+\left(62.1+0.46 x_{1}+20.53 x_{2}-1.42 x_{3}+\right. \\
& \left.74.3 x_{4}-2.29 x_{5}\right)\left(y_{2} \geq 22.43\right) .
\end{aligned}
$$






Fig. 4. Dependence of theoretical and factual values on water absorption

Multidimensional correlation and determination coefficients of empirical Eqs 10-11 presented in Table 6 shows, that there is a strong relation between selected drying stages and structural indexes and mathematical model, which were used to describe data are selected properly, because the values of the coefficients of correlation and determination are close to one. The average standard deflection obtains quite low values, therefore theoretical, i.e. calculated according to obtained empirical equations and factual values, differ slightly.

Table 6. Multidimensional correlation $R$ and determination $R^{2}$ coefficients, average standard deviations $s_{\mathrm{e}}$ of empirical equations $10-11$

\begin{tabular}{c|l|c|c|c}
\hline $\mathrm{Eq}$ & Indexes & $R$ & $R^{2}$ & $s_{e}$ \\
\hline 10 & $\begin{array}{l}\text { The stage of drying in a } \\
\text { laboratory, } y_{1}\end{array}$ & 0.977 & 0.954 & 2.75 \\
\hline 11 & $\begin{array}{l}\text { The stage of drying in } \\
\text { the electrical stove, } y_{2}\end{array}$ & 0.971 & 0.943 & 3.59 \\
\hline
\end{tabular}

Eq 10 shows, how the value of the stage of drying in a laboratory changes depending on the selected values of structural indexes, which we want to obtain. Water absorption of ceramic chip influences negatively the stage of keeping under normal conditions in a laboratory, because, as it was mentioned before, the sample dries evenly, smaller number of inner strains is produced, the degree of defects of semi-manufacture decreases and we obtain ceramics with smaller number of open pores and capillaries. Other indexes influence differently before and after epoch (24.11 (Eq 10)). For example, if we select higher reserve of porous volume and lower degree of heterogeneity of structure and capillary rate of mass flow, we will obtain higher values of drying in a laboratory but not higher than 24.11.

We can work out from Eq. 11, how the values of structural indexes, which we want to obtain, influence the value of the drying stage in a laboratory. The lower maximum rate of capillary rise according to watering front and higher reserve of porous volume of ceramics, which effective porosity is higher than $26 \%$, we select, the higher value of drying in the electrical stove we obtain. As it was mentioned before, the values of porous volume of ceramics increase, and the values of maximum rate of capillary rise, according to watering front, decrease when semimanufactures are being dried evenly and for a quite long time. Other structural indexes influence differently the value of the stage of drying in the electrical stove before and after epoch (22.43 (Eq 11)). For example, if we select higher degree of heterogeneity of structure (after epoch 22.43), capillary rate of mass flow and lower water absorption, when effective porosity of investigated ceramics is higher than $26 \%$, the higher value of the drying stage in a laboratory we obtain. The stage of drying in a laboratory (especially than it is higher when 22.43) begins to influence positively the degree of heterogeneity of structure and capillary rate of mass flow, because moisture does not evaporate from the inner layers on time, and semi-manufacture develops structure which is uneven and has more open pores and capillaries.

\section{Example of usage of empirical equations}

We present the example of usage of empirical equations when we only vary the values of the selected parameters of drying regime and all the other technological conditions are stable. Formation mix of ceramic samples was prepared from: clay, sand, chip and cuttings. It was burned for 36 hours, keeping at the maximum temperature of $1050{ }^{\circ} \mathrm{C}$ for 3 hours.

Example. If we want to obtain production with appropriate structural indexes, e.g. reserve of porous volume $25 \%$, degree of heterogeneity of structure 0.4 , maximum rate of capillary rise according to watering front $25 \mathrm{~mm}$, capillary rate of mass flow $0.4 \mathrm{~g} / \mathrm{cm}^{2}$, water absorption $17 \%$, we insert values into the equations $10-11$ (it is used that part of the equation which has a lower consumption of energy ) and obtain such parameters of drying regime: the value of the drying stage in a laboratory 15.1 and drying in a stove -15.8 (at $105^{\circ} \mathrm{C}$ ).

In order to ascertain reliability of parameters of drying regime which were obtained, we insert values which were calculated in the Eqs 5-9 and obtain, that reserve of porous volume equals $-24 \%$, degree of heterogeneity equals -0.4 , maximum rate of capillary rise according to watering front $26 \mathrm{~mm}$, capillary rate of mass flow $-0.4 \mathrm{~g} / \mathrm{cm}^{2}$, water absorption $-17 \%$. These results are in Table 7 .

Table 7. Results of usage of empirical equations

\begin{tabular}{l|c|c|c|c|c}
\hline Parameter & $\begin{array}{c}R_{p} \\
x_{1}, \\
\%\end{array}$ & $\begin{array}{c}N_{h} \\
x_{2}\end{array}$ & $\begin{array}{c}H_{\max } \\
x_{3}, \\
\mathrm{~mm}\end{array}$ & $\begin{array}{c}g \\
x_{4}, \\
\mathrm{~g} / \mathrm{cm}^{2}\end{array}$ & $\begin{array}{c}W_{h} \\
x_{5}, \\
\%\end{array}$ \\
\hline $\begin{array}{l}\text { Chose structural } \\
\text { parameters }\end{array}$ & 25 & 0.4 & 25 & 0.4 & 17 \\
\hline $\begin{array}{l}\text { Calculatedstructural } \\
\text { parameters }\end{array}$ & 24 & 0.4 & 26 & 0.4 & 17 \\
\hline
\end{tabular}

here: $R_{p}$ - rezerve of porous volume, $N_{h}$ - heterogeneity degree of structure, $H_{\max }$ - maximum rate of capillary rise according to watering front, $g$ - capillary rate of mass flow, $W_{h}$ - water absorption. 
Therefore, the values obtained differ extremely slightly from the selected characteristics of the ceramic article.

\section{Conclusions}

1. It is determined that relation between the stages of selected drying regimes and structural indexes which were investigated is very strong. The values of multidimensional correlation coefficients describing relation are $\mathrm{R}=0.845-0.977$.

2. It is proved, that the drying regime is selected properly, when all other technological factors are stable, and can significantly improve characteristics of the final ceramic product. For example, the value of porous volume can increase from approximately $19 \%$ to $27 \%$.

3. There are presented examples how to use the empirical equations obtained. Checking corresponding of experimental results to the values calculated according to empirical equations, it is determined, that all the other technological factors do not fluctuate. It is possible to select drying regime according to structural indexes which we want to obtain. And, conversely, it is possible to forecast final structural indexes of ceramic article when selecting drying regime.

\section{References}

Alinaitwe, H. M.; Mwakali, J. A.; Hansson, B. 2007. Factors affecting the productivity of building craftsmen - studies of Uganda, Journal of Civil Engineering and Management 13(3): 169-176.

Amoros, J. L.; Sanchez, E.; Cantavella, V.; Jarque, J. C. 2003. Evolution of the mechanical strength of industrially dried ceramic tiles during storage, Journal of the European Ceramic Society 23(11): 1839-1845.

Barati, A.; Kokabi, M.; Famili, M. H. N. 2003. Drying of gelcast ceramic parts via the liquid desiccant method, Journal of the European Ceramic Society 23(13): 2265-2272.

Briscoe, B. J.; Biundo, G. Lo; Özkan, N. 1998. Drying kinetics of water-based ceramic suspensions for tape casting, $\mathrm{Ce}$ ramics International 24(5): 347-357.

Croft, A. P.; Sheffield, B. D. 1994. Process to increase the drying rate of a glaze for ceramics, Appl. No. 07/891,330.

Čekanavičius, V.; Murauskas, G. 2002. Statistika II ir jos taikymas [Statistics and its practice]. Vilnius: TEV. 268 p.

Ginevičius, R.; Podvezko, V.; Raslanas, S. 2008. Evaluating the alternative solutions of wall insulation by multicriteria methods, Journal of Civil Engineering and Management 14(4): 217-226.

Graybill, F. A.; Iyer, H. K. 1994. Regression analysis. Belmont, California: Wandsworth Publishing Company. 701 p.

Kleinbaum, D. G.; Kupper, L. L.; Muller, K. E.; Niram, A. 1998. Statistical analysis. Brooks/Cole Publishing Company. $798 \mathrm{p}$.

Kosykh, V.; Lokhova, N. A.; Maksimova, S. M. 2003. Raw mixture and method for preparing ceramic article with reduced density. No. RU2206538.
Lewis, J. A. 2000. Colloidal processing of ceramics, Journal of the American Ceramic Society 83(10): 2341-2359.

LST EN 771-1+A1. 2005. Mūro gaminiu techniniai reikalavimai. 1 dalis. Keraminiai mūro gaminiai [Specification for masonry units - Part 1: Caly masonry units]. Vilnius: Lietuvos standartizacijos departamentas. $47 \mathrm{p}$.

Mačiulaitis, R.; Malaiškienè, J.; Kičaitè, A. 2008. The regulation of physical and mechanical parameters of ceramic bricks depending on the drying regime, Journal of Civil Engineering and Management 14(4): 263-268.

Mačiulaitis, R.; Malaiškienė, J.; Kičaite, A. 2007. Influence of drying on the final properties of ceramics, in Proceedings of $9^{\text {th }}$ International Conference "Modern Building Materials, Structures and Techniques" held on May 16-18, 2007. Vilnius: Technika, Vol. 1: 113-118. ISBN 9789955-28-198-6.

Mačiulaitis, R. 1996. Frost resistance and durability of façade bricks. Frostwiderstand und Dauerhaftigkeit keramischer Fassadenerzeugnisse. Fasadines keramikos atsparumas šalčiui ir ilgaamžiškumas. Vilnius: Technika. 132 p.

Mačiulaitis, R.; Malaiškienè, J. 2008. Possibilities to control ceramics properties by changing firing cycles, Construction and Building Materials 23(1): 226-232.

Malaiškienè, J.; Mačiulaitis, R. 2004. New possibilities of quality regulation for ceramic products, Journal of Civil Engeneering and Management 10(1): 37-43.

Mihoubi, D.; Zagrouba, F.; Amor, B.; Bellagi, A. 2002. Drying of clay and material characteristics, Drying Technology 20(2): 465-487.

Nascimento, J. J. S.; Lima, A. G. B.; Teruel, B. J.; Belo, F. A. 2006. Heat and mass transfer with schrinkage during the drying of ceramic bricks, Informacion Technologica 17(6): 145-151.

Ostle, B.; Turner, Jr.; Hicks, CH. R.; Mc Elrath, G. W. 1996. Engineering statistics. The Industrial Experience. Belmont, California: Wandsworth Publishing Company. $568 \mathrm{p}$.

Sakalauskas, V. 1998. Duomenu analizè su statistika [Data analysis with Statistics]. Vilnius: Margi raštai. 227 p.

Šiaučiūnas, R. 2001. Keraminiu medžiagu cheminè technologija [Chemical technology of ceramic materials]. Kaunas: Technologija. 189 p.

Zavadskas, E. K.; Kaklauskas, A.; Turskis, Z.; Tamošaitienė, J. 2008. Selection of the effective dwelling house walls by applying attributes values determined at intervals, Journal of Civil Engineering and Management 14(2): 85-93.

Мачюлайтис, Р. 1997. Морозостойкость и долговечность изделий фасадной керамики [Maciulaitis, R. Frostresistance and durability of facade ceramic products]. Вильнюс: Техника. $307 \mathrm{c}$.

Манита, А. Д. 2001. Теория вероятностей и математическая статистика [Manita, A. D. Theory of chances and mathematical statistics]. Москва: Издат. отдел УНЦ ДО. $120 \mathrm{c}$.

Ткачев, А. Г.; Козярений, А. Я.; Ткачева, О. Н. 1999. Оптимизация рецептуры кирпичной массы по сушильным свойствам [Tkachev, A. G.; Kozyarskii, A. Ya.; Tkaceva, O. N. Optimization of the brick mass composition on the basis of drying properties], Стекло $u$ керамика [Glass and Ceramics] 8: 33-34. 


\section{DŽIOVINIMO REŽIMO IૃTAKA KERAMIKOS STRUKTŪRINIŲ CHARAKTERISTIKŲ VERTĖMS}

\section{R. Mačiulaitis, J. Malaiškienė}

\section{S antrauka}

Džiovinimas gaminant keraminius dirbinius yra labai svarbus technologinis procesas, nes džiovinant turi baigtis keraminių bandinių tūrio pokyčiai, susiję su drègmès pasišalinimu, kad neatsirastų defektų - plyšių, itrūkių, nuskilimų ir t. t. Darbe buvo išnagrinèta, kaip džiovinimo režimo parinkimas gali lemti defektų atsiradimą ir tokias struktūrines keraminiu bandinių charakteristikas, kaip poringosios erdvès rezervas, struktūros nevienalytiškumo laipsnis, maksimalus kapiliarinio pakilimo pagal drèkinimo frontą greitis, kapiliarinis masès srauto greitis ir vandens imirkis. Tikslui pasiekti keraminiai bandiniai buvo paruošti parinkus 8 džiovinimo režimus, o kitus technologinius veiksnius (formavimo mišinio sudètis, degimo temperarūra, temperatūros kèlimo greitis degant ir kt.) palikus nekintamus. Nustačius keraminès šukès struktūrines charakteristikas ir atlikus gautų duomenų statistinę analizę, buvo sudarytos empirinès lygtys. Pagal jas buvo pagrịsta, kaip kiekvienas parinktas džiovinimo režimo etapo dydis lemia struktūrinių rodikliu verčių kitimą ir kaip galima reguliuoti džiovinimo režima, norint gauti tam tikras struktūinių charakteristikų vertes.

Reikšminiai žodžiai: keramika, struktūriniai rodikliai, džiovinimo režimas, statistinè analizè.

Romualdas MAČIULAITIS. Prof., Doctor Habil of Technological Sciences. He works at Dept of building materials of Vilnius Gediminas Technical University (VGTU). Research interests: development of building materials and analysis of their characteristics.

Jurgita MALAIŠKIENÉ. Doctor of Civil Engineering. She works at Dept of building materials of Vilnius Gediminas Technical University (VGTU). Research interests: development of new conglomerates from local resources, research of their properties and possibilities to use them. 